\title{
Limits of the Novel
}

\author{
Evolutions of a Form \\ from Chaucer to Robbe-Grillet
}





\title{
Limits of the Novel
}

\section{Evolutions of a Form}

from Chaucer to Robbe-Grillet

\section{DAVID I. GROSSVOGEL}

Cornell Paperbacks

Cornell University Press

\author{
ITHACA AND LONDON
}




\section{Copyright (c) 1968 by Cornell University}

All rights reserved. Except for brief quotations in a review, this book, or parts thereof, must not be reproduced in any form without permission in writing from the publisher. For information address Cornell University Press, 124 Roberts Place, Ithaca, New York 14850.

First published 1968

First printing, Cornell Paperbacks, 1971

Quotations from Jean-Paul Sartre, Nausea, translated by Lloyd Alexander, Copyright (C) 1964 by New Directions Publishing Corporation, reprinted by permission of New Directions Publishing Corporation. Quotations from The Ingenious Gentleman Don Quixote de la Mancba, Volumes I and II, by Miguel de Cervantes Saavedra, translated by Samuel Putnam, Copyright 1949 by The Viking Press, Inc., reprinted by permission of The Viking Press, Inc.

International Standard Book Number 0-8014-91 15-0

Library of Congress Catalog Card Number: $68-163_{3} 81$

PRINTED IN THE UNITED STATES OF AMIERICA

BY VAIL-BALLOU PRESS, INC. 


\section{Per John}

\section{L'intero libro invece}

di tante note 
